\title{
Specifics of soil temperature under winter wheat canopy
}

\section{Jana KRČMÁŘOVÁ ${ }^{1}$, Hana STŘEDOVÁ ${ }^{2}$, Radovan POKORNÝ1, Tomáś STŘEDA ${ }^{1,3}$}

${ }^{1}$ Department of Crop Science, Breeding and Plant Medicine, Mendel University in Brno Zemědělská 1, 61300 Brno, Czech Republic e-mail: jana.krcmarova@mendelu.cz, radovan.pokorny@mendelu.cz

${ }^{2}$ Department of Applied and Landscape Ecology, Mendel University in Brno Zemědělská 1, 61300 Brno, Czech Republic; e-mail: hana.stredova@mendelu.cz

${ }^{3}$ Czech Hydrometeorological Institute, Brno - Branch Office

Kroftova 43, 61667 Brno, Czech Republic; e-mail: tomas.streda@chmi.cz

\begin{abstract}
The aim of this study was to evaluate the course of soil temperature under the winter wheat canopy and to determine relationships between soil temperature, air temperature and partly soil moisture. In addition, the aim was to describe the dependence by means of regression equations usable for phytopathological prediction models, crop development, and yield models. The measurement of soil temperatures was performed at the experimental field station Žabčice (Europe, the Czech Republic, South Moravia). The soil in the first experimental plot is Gleyic Fluvisol with $49-58 \%$ of the content particles measuring $<0.01 \mathrm{~mm}$, in the second experimental plot, the soil is Haplic Chernozem with $31-32 \%$ of the content particles measuring $<0.01 \mathrm{~mm}$. The course of soil temperature and its specifics were determined under winter wheat canopy during the main growth season in the course of three years. Automatic soil temperature sensors were positioned at three depths $(0.05,0.10$ and $0.20 \mathrm{~m}$ under soil surface), air temperature sensor in $0.05 \mathrm{~m}$ above soil surface. Results of the correlation analysis showed that the best interrelationships between these two variables were achieved after a 3-hour delay for the soil temperature at $0.05 \mathrm{~m}, 5$-hour delay for $0.10 \mathrm{~m}$, and 8-hour delay for $0.20 \mathrm{~m}$. After the time correction, the determination coefficient reached values from 0.75 to 0.89 for the depth of $0.05 \mathrm{~m}$, 0.61 to 0.82 for the depth of $0.10 \mathrm{~m}$, and 0.33 to 0.70 for the depth of $0.20 \mathrm{~m}$. When using multiple regression with quadratic spacing (modeling hourly soil temperature based on the hourly near surface air temperature and hourly soil moisture in the $0.10-0.40 \mathrm{~m}$ profile), the difference between the measured and the model soil temperatures at $0.05 \mathrm{~m}$ was -2.16 to $2.37^{\circ} \mathrm{C}$. The regression equation paired with alternative agrometeorological instruments enables relatively accurate modeling of soil temperatures $\left(\mathrm{R}^{2}=0.93\right)$.
\end{abstract}

Key words: soil temperature, canopy, microclimate, sum of effective temperatures 


\section{Introduction}

Air temperature data are more readily available and more easily collected than soil temperature data. However, monitoring of soil temperatures is necessary for a number of agronomic and phenological purposes, for soil respiration quantification, microbial transformations of sulphur and nitrogen (in wheat canopy Weber and Rennenberg, 1996), for estimating belowground processes for carbon budgets, evaporation etc. As early as in the 1940 s, Wort (1940) tested the impact of different temperatures $\left(22-42{ }^{\circ} \mathrm{C}\right)$ on the growth of Marquis spring wheat. Similarly, the effects of rising soil temperature, soil hydrothermal properties, winter wheat growth and yield were studied by Ju et al. (2010). Franzaring et al. (2010) conclude that also $\mathrm{CO}_{2}$ enrichment was responsible for changes of the soil microclimate.

Knowledge concerning soil temperature is inevitable for modeling of some plant growth and development models. Moreover, it is sometimes used for the prediction of pathogens and pest occurrence. Soil temperature in crop simulation models CERES (CERES-Wheat, CERES-maize etc.) is simulated using daily air temperature data, soil moisture status and available water content, albedo, solar radiation and the day of the year. The absence of data of soil temperatures from the canopy is often the limiting factor for crop simulation models. The poorer results of those models were likely caused by inaccurate simulation of ground-level soil temperatures (Casanova et al., 2006; Wang et al., 2009). Farmers need this data or a simple algorithm that will enable relatively accurate deduction based on standard measurements of meteorological characteristics. For these purposes, the data regarding soil temperature recorded at standard climatological stations are used. They can differ from actual soil temperatures in or under the crop stands. For these reasons, the collected data should be also compared for different crop stands and soil management systems.

The shape, dimensions and the geometrical structure of a specific plant species play important roles in the development of the canopy microclimate (Matejka and Huzulák, 1987; Chelle et al., 2009). Porté et al. (2004) pointed out the buffer effect of the forest cover: the daily range was large in the open site (up to $9.7^{\circ} \mathrm{C}$ ); but it was attenuated in the "pine", the "semi-mature" and the "mixed" stands (up to $3.3^{\circ} \mathrm{C}, 3.1{ }^{\circ} \mathrm{C}$ and $2.0^{\circ} \mathrm{C}$, respectively). Pierson and Wight (1991) reported that the amplitude of diurnal variability in 
soil temperature (fine loamy over sandy or sandy skeletal soil) in the depth of $1 \mathrm{~cm}$ under sagebrush (Artemisia tridentata ssp. tridentata) was similar to the amplitude of the diurnal variability in the depth of $10 \mathrm{~cm}$ within the interspaces. The impact of various forest surfaces on the date of reaching the maximum daily soil temperature was studied by Devine and Harrington (2007).

Surface residue cover can affect soil temperature by insulating the soil surface and slowing soil drying in spring (Fortin, 1993). Different tillage systems can also influence the temperature of soil and the growth of wheat (He et al., 2012). Soil temperature increased in the top $5 \mathrm{~cm}$ under striptillage $\left(1.2-1.4^{\circ} \mathrm{C}\right)$ over no-tillage and it remained close to the chisel plow soil temperature (Licht and Al-Kaisi, 2005). In weed-control experiments by Han et al. (2013), spike numbers were significantly lower under no-tillage than under conventional tillage, possibly because soil temperature under no-tillage was decreased, and hence affected the growth and development of tillers after spring.

The relationship between air and soil temperatures within the agrosystem was described by several studies (for chili, onion and pecan - Sharma et al., 2010; for maize and alfalfa - Luo et al., 1992; for maize - Gupta et al., 1981 and others). The specifics of soil temperatures, their vertical stratification under the canopy and the possibilities of data rows reconstruction adapted to the conditions of Czech Republic were described by Pokladniková and Rožnovský (2006 and 2007). The aim of the study by Krčmářová et al. (2013) was to evaluate the course of soil temperatures under the wheat canopy, and to determine relationships between soil temperatures under various plant covers.

Nevertheless, there are not many studies evaluating the soil microclimate under the canopy in regard to major field crops suitable for mid-European climate (wheat, barley, potatoes, sugar beet, oil rape). There are significantly more works dealing with soil temperatures for soils under forest stands, including soil temperature modeling based on air temperatures.

The aim of this study was to evaluate the course of soil temperatures under the winter wheat canopy and to determine relationships between soil temperature, air temperature and partly soil moisture. 


\section{Material and methods}

The measurement was performed at the experimental field station Žabčice (Europe, the Czech Republic, South Moravia). The experimental area is located in the floodplain of the Svratka River at an altitude of approximately $184 \mathrm{~m}$ a.s.l. in a maize production area. The long-term (1991-2010) average air annual temperature is $10.0^{\circ} \mathrm{C}$, and the annual precipitation total is $496 \mathrm{~mm}$ (Žalud et al., 2013). According to the agroclimatic classification (Kurpelová et al. 1975), the location belongs to the warm macro area, predominantly warm (annual air sum of effective temperature above $10^{\circ} \mathrm{C}$ 2840 degree days) and dry sub-region (annual potential evapotranspiration minus annual precipitation total $15.5 \mathrm{~mm}$ ) with mild winters (average of annual absolute minimum air temperatures $-17.4^{\circ} \mathrm{C}$, annual average number of days with snow cover occurrence 45.6).

Soil types were classified according to Němeček et al. (2001). The soil in the experimental plot Obora (Obo) is heavy clayey-loam Gleyic Fluvisol with $49-58 \%$ of the content particles measuring $<0.01 \mathrm{~mm}$. The soil in the experimental plot Pisky (Pis) is medium heavy loamy Haplic Chernozem with $31-32 \%$ of the content particles measuring $<0.01 \mathrm{~mm}$.

The experimental field was planted with winter wheat (Sultan variety) in 2010, 2011, and 2013. The spacing of the canopy was $0.125 \mathrm{~m}$ between rows, in a population of 3.5 (Obo) and 4.5 (Pis) million plants per ha. At maturity, the average number of spikes was about 610 (Obo) and about 380 (Pis).

Soil and air temperatures were measured by automatic digital temperature sensors (Dallas semiconductor, DS18B20 type). The near surface air temperature sensor was placed in a radiation shield in $0.05 \mathrm{~m}$ level above soil surface in wheat canopy. The soil sensors were placed in the soil under the winter wheat canopy in the depths of $0.05,0.10$, and $0.20 \mathrm{~m}$ under soil surface. The data were taken and stored in a data logger at fifteen-minute intervals. The hourly values of air and soil temperatures were obtained as the arithmetic average of the fifteen-minute data. The VIRRIB (Amet, Velké Bílovice) sensors were used for measuring the volumetric soil moisture in the Obora locality. The sensors measure hourly temperatures in the 0.10-0.40 m soil profile.

With regard to the technical and time requirements of the exact estab- 
lishment of leaf area index - LAI (the practice requires a simple and fast method of canopy evaluation), canopy growth and its stages were measured according to the $\mathrm{BBCH}$ scale (Meier, 199'7). The vegetation period of wheat was divided into three stages: I. BBCH 23-32 (tillering to beginning of stem elongation), II. BBCH 33-69 (stem elongation to the end of flowering) and III. BBCH 70-89 (development of fruit and ripening).

The range of the soil temperatures was plotted as a box plot. The regression analysis was carried out to evaluate interrelationships between soil temperatures measured under the winter wheat canopy and air temperature in the same canopy. As the course of temperatures in soil can be delayed, cross correlations were computed for this evaluation (software STATISTICA, ver. 7 ). These models were tested with the coefficient of determination $\left(\mathrm{R}^{2}\right)$.

For soil temperature modeling based on the near surface air temperature and soil moisture in the $0.10-0.40$ profile, the multiple regression method with quadratic spacing was used (software STATISTICA, ver. 7).

The average soil temperature (from fifteen-minute data) in the Obo locality, per each year and period, was delineated in the form of 2D nomogram (software SURFER, ver. 10) by means of the Kriging interpolation method.

\section{Results and discussion}

Descriptive statistics of the three-year monitoring results (2010, 2011, and 2013) covering soil temperatures under the wheat canopy in three depths $(0.05,0.10$ and $0.02 \mathrm{~m})$ on two localities (Obo and Pis) with different soil conditions are displayed in Fig. 1. The 2012 experiment was damaged by drought. The average soil temperatures in the course of the main vegetation period of winter wheat ranged from $12.46{ }^{\circ} \mathrm{C}$ (Obo, $\left.0.20 \mathrm{~m}, 2011\right)$ to $16.43^{\circ} \mathrm{C}$ (Pis, $0.05 \mathrm{~m}, 2011$ ). The maximum difference between localities with respect to the average vegetation soil temperatures was found in 2011 , at $20 \mathrm{~cm}$ (Obo $12.46^{\circ} \mathrm{C}$, Pis $15.96^{\circ} \mathrm{C}$ ). A distinctive difference between localities caused by diverse soil conditions and canopy structure was confirmed. Meteorological conditions were identical on both localities as the distance between the trial plots was minimal (ca $2 \mathrm{~km}$ ). Especially in 2010 which was a year with a lot of precipitation, minimal differences among soil temperatures in different depths and also between localities were found (the 


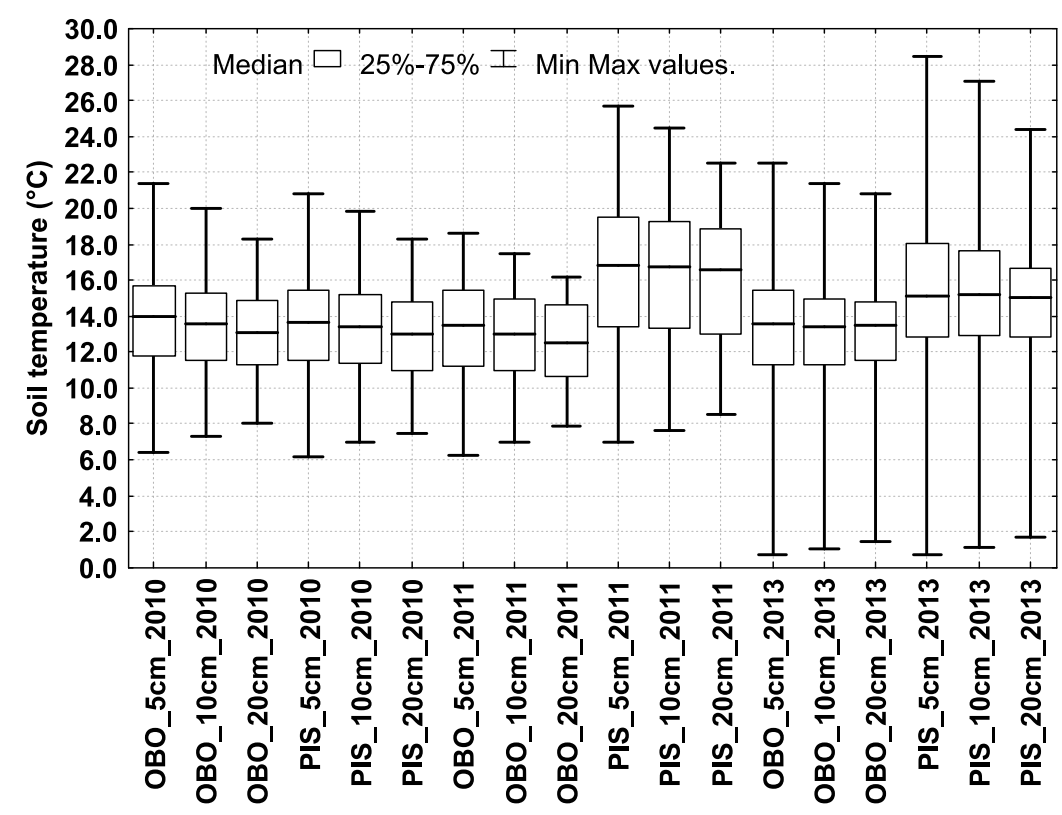

Fig. 1. The range of soil temperatures under winter wheat canopy and its descriptive statistics. Notes: OBO_5cm_2010 = Obora locality, $0.05 \mathrm{~m}$ depth, 2010 year, etc.

difference among the average values was only $0.83^{\circ} \mathrm{C}$ ). This is also evident from Fig. 2 which displays the sums of effective soil temperatures above $5{ }^{\circ} \mathrm{C}$ in the depth of $0.05 \mathrm{~m}$ and describes the dynamics of soil temperatures in the course of time. The presented phenomenon which is related to energy balance and heat flux into the soil for different plant canopies (Hurtalová and Matejka, 1999) was caused by abnormal precipitation, below-average sunshine (sunshine hours) values and high production of biomass. Vegetation cover increased (corrected) the soil surface temperatures at night by reducing convective and radiative heat loss from the ground surface.

This is also manifested in the year-on-year soil temperatures evaluation from the Obo locality (average in the profile of $0.05-0.20 \mathrm{~m}$ in 2010 $-13.45^{\circ} \mathrm{C}$ and standard deviation 2.84 , in $201112.83^{\circ} \mathrm{C}$ and 2.52 , in 2013 $12.69^{\circ} \mathrm{C}$ and 4.19 ). The low difference of mean soil temperature values and their dynamics in the course of the vegetation season are influenced by higher water content in heavy soil and a high level of underground wa- 


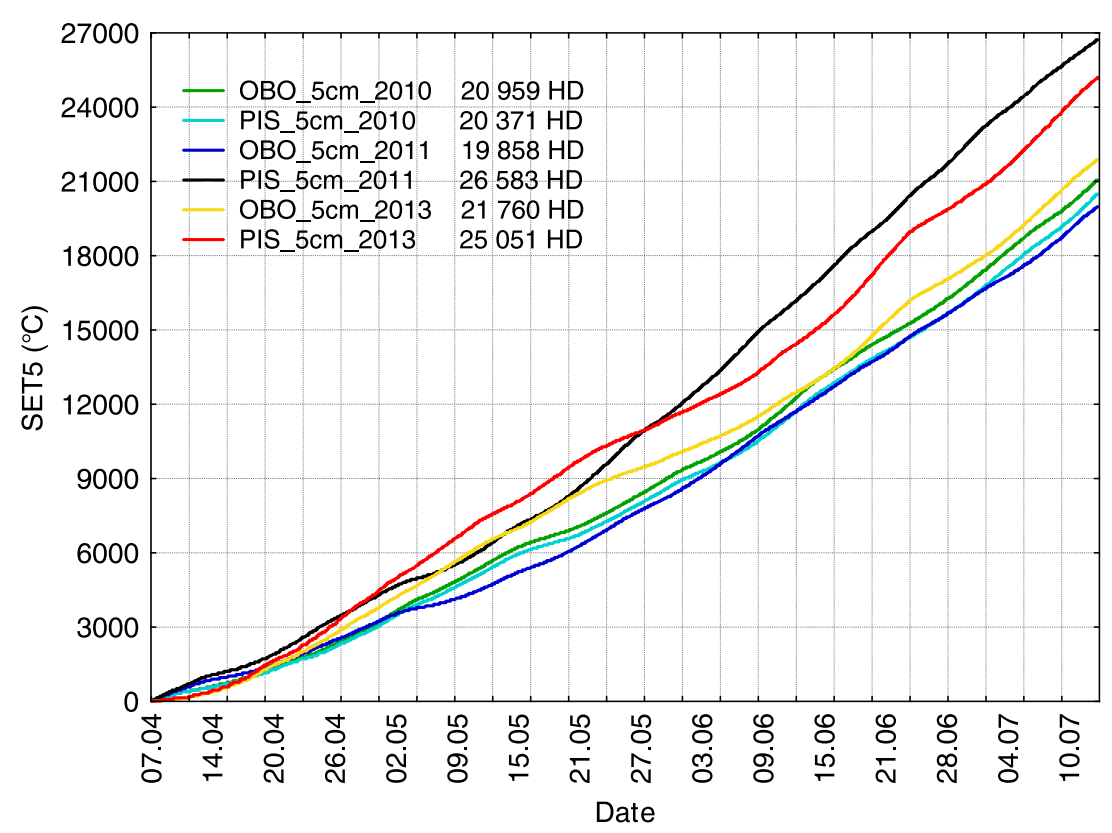

Fig. 2. Dynamics of soil temperatures under winter wheat canopy during vegetation periods expressed as the sum of hourly effective temperatures above $5{ }^{\circ} \mathrm{C}$. Notes: OBO_5cm_2010 = Obora locality, $0.05 \mathrm{~m}$ depth, 2010 year, etc.; HD = hourly degrees.

ter. In contrast, the Pis locality (medium to light soil on the gravel) shows higher soil temperatures and amplitudes. The average soil temperature in the $0.05-0.20 \mathrm{~m}$ profile was $13.23^{\circ} \mathrm{C}$ in 2010 and the standard deviation was 2.85 , in 2011 the average soil temperature was $16.22^{\circ} \mathrm{C}$ and 3.78 , in 2013 $15.14{ }^{\circ} \mathrm{C}$ and 4.07 .

The course of soil temperatures during vegetation, expressed in Fig. 2 as a cumulative sum of temperatures above $5{ }^{\circ} \mathrm{C}$ (SET5), is also important for prediction and signalization of poikilotherm organisms (pests). In connection with soil pest Western Corn Rootworm occurrence prediction, the hourly and daily soil sum of effective temperatures in the maize canopy in Czech Republic was evaluated by Středa et al. (2013). Likewise, similar study was carried out in Switzerland by Derron et al. (2005). For most pests, the temperature of soil in the upper part of the soil profile is of key importance. Average daily increase of SET5 at $0.05 \mathrm{~m}$ (three-year monitor- 
ing) was 215 hourly degree (HD) on the Obo locality, $247 \mathrm{HD}$ on the Pis locality (that is $15 \%$ difference). The maximum difference of seasonal SET5 values on the Obo and Pis localities (Fig. 2) is $6725 \mathrm{HD}$. It is interesting that the highest as well as lowest SET5 values were reached in 2011. This is mainly a result of different temperature and moisture regimes of light and heavy soils, meteorological conditions during the vegetation season and the distinctive impact of the canopy (varied canopy structures were used). It is well known that the soil surface temperature is highly correlated with light penetration through the canopy. In the study of Prévost and Pothier (2003), significant increases by several degrees of summer soil temperature were found in the 50, 65 and $100 \%$ cuttings of a mixed aspen-conifer stand.

Sándor and Fodor (2012) present that the crop cover significantly influences the soil temperature dynamics of the upper soil layers. Therefore, considering the LAI in a model calculation is indispensable. In this respect, the vegetation period of winter wheat was divided into three stages in our experiment. Detailed course of daily soil temperatures and their stratification within the soil profile were expressed by means of $2 \mathrm{D}$ nomograms (Fig. 3-5) for each vegetation period. Data from the Obo locality during vegetation periods I to III in 2010, 2011 and 2013 were used for creation of the nomograms. Based on this data, it is possible to describe the daily regime of soil temperatures under the winter wheat canopy during important growth stages. The impact of winter wheat, spring barley and ley in comparison with bare soil (heavy clay) during the growth period was also studied by Rodskjer et al. (1989). In the case of spring barley, the effect of the stand on soil temperature ocurred in the upper soil layer when leaf area index was about 1 . The lag of an obvious temperature difference between the bare soil and the barley increased with depth.

Furthermore, the detailed time and vertical profiles of soil temperatures enable estimation of their impact on pedo-chemical, pedo-biological and phenological processes. However, for example, McMaster and Wilhelm (1998) presented that in no instance did soil temperature significantly improve prediction of winter wheat phenology (in comparison with air monitoring outcomes). Exact quantification of year-on-year soil temperature difference, even in depths where direct monitoring is not carried out, can be conducted by means of interpolated values. In the case of annual soil temperature monitoring, zero degree isotherm is identified (Středová et al., 

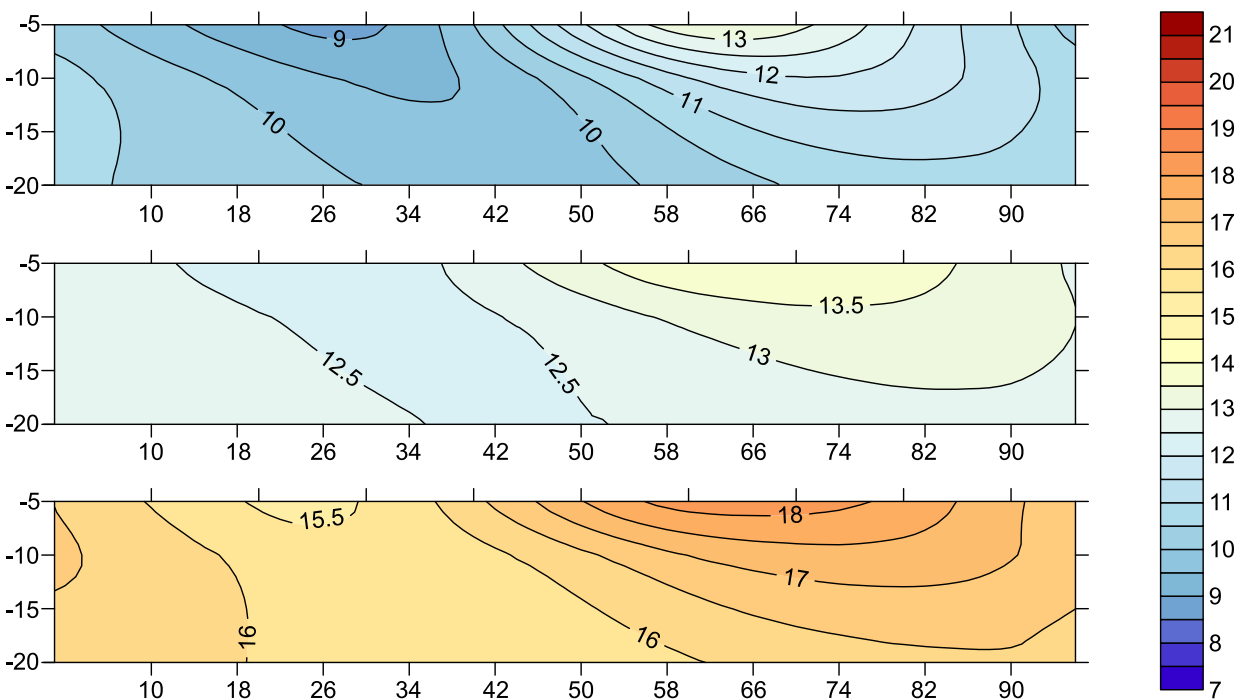

Fig. 3. 24-hour course (x-axis, expressed in 15-minute intervals) of soil temperatures $\left({ }^{\circ} \mathrm{C}\right)$ in the 0.05-0.20 m soil profile (y-axis, expressed in centimetre) in 2010 (Obo locality), from above: 1st, 2nd and 3rd stages.
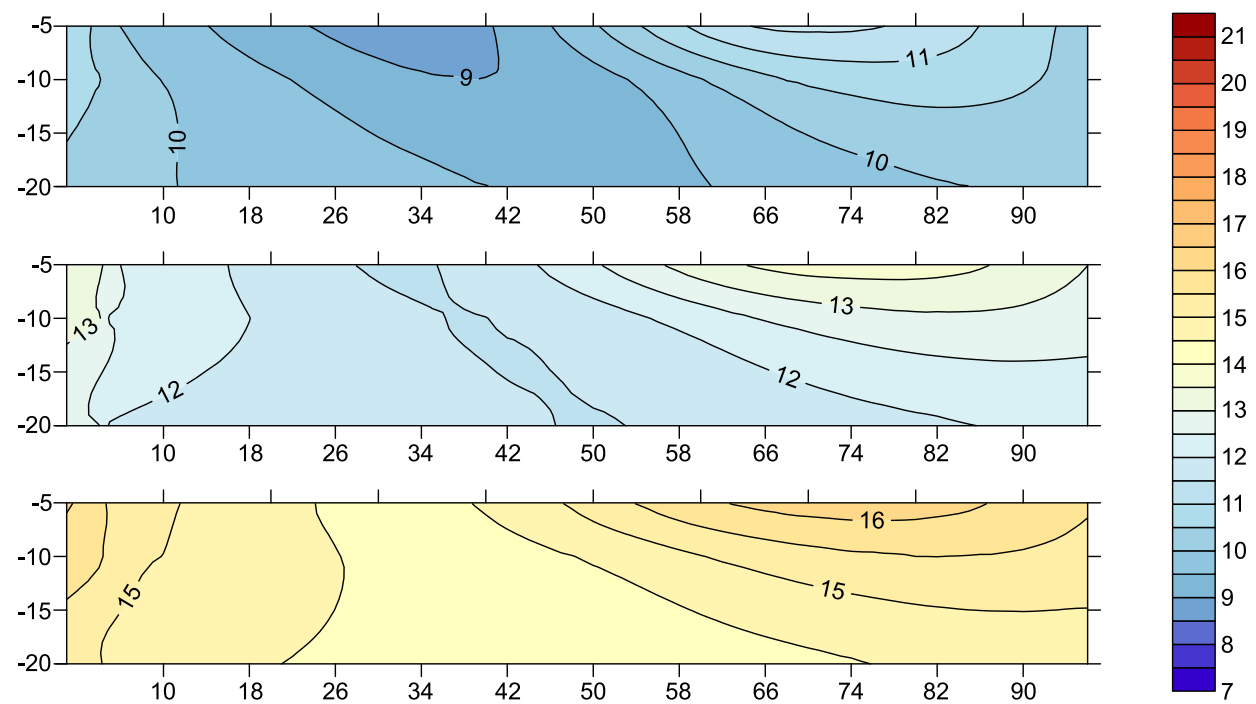

Fig. 4. 24-hour course (x-axis, expressed in 15-minute intervals) of soil temperatures $\left({ }^{\circ} \mathrm{C}\right)$ in the 0.05-0.20 m soil profile (y-axis, expressed in centimetre) in 2011 (Obo locality), from above: 1st, 2nd and 3rd stages. 

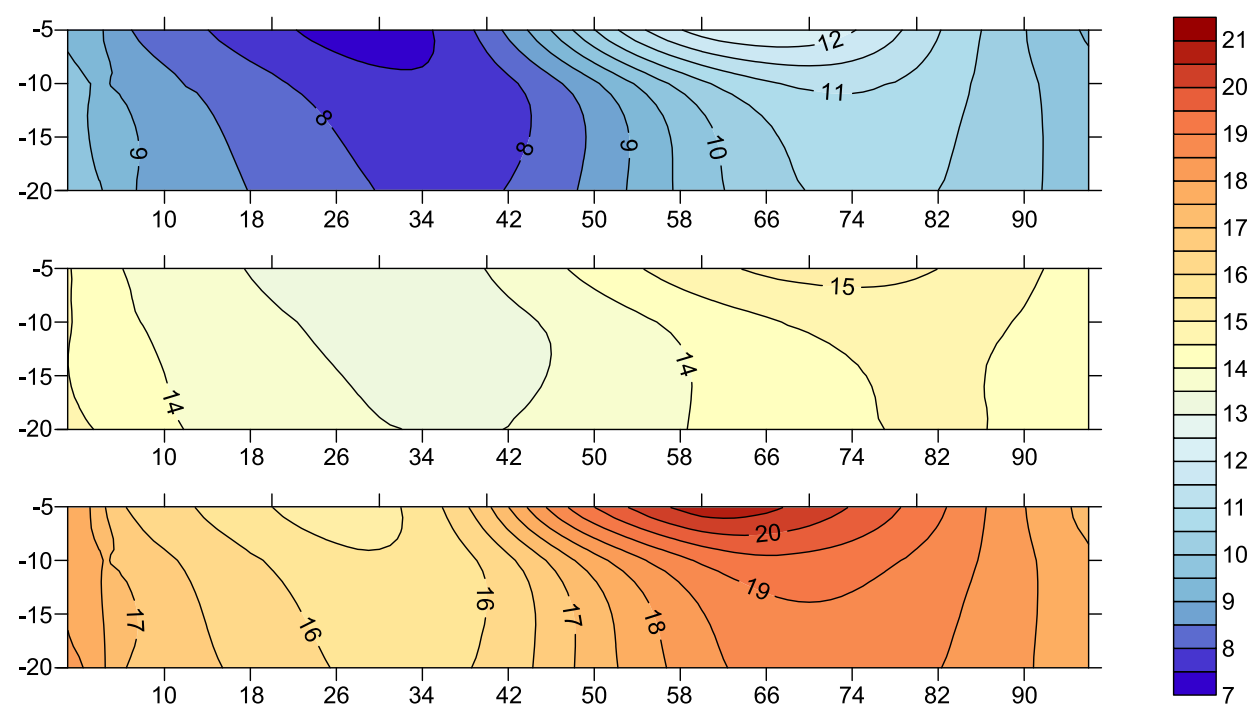

Fig. 5. 24-hour course (x-axis, expressed in 15-minute intervals) of soil temperatures $\left({ }^{\circ} \mathrm{C}\right)$ in the $0.05-0.20 \mathrm{~m}$ soil profile (y-axis, expressed in centimetre) in 2013 (Obo locality), from above: 1st, 2nd and 3rd stages.

2012).

The dependence of hourly soil temperature under winter wheat canopy on the hourly near surface air temperature was also evaluated (Table 1). However, the prediction of soil temperature in the winter wheat canopy can not be done from the air temperature in the ground of winter wheat canopy recorded at the same time (for example Krčmářová et al., 2013). As it was found out by a cross correlation analysis, the best interrelationships between these two variables were achieved after a 3-hour delay for the soil temperature in $0.05 \mathrm{~m}, 5$-hour delay for $0.10 \mathrm{~m}$ and 8-hour delay for $0.20 \mathrm{~m}$. After the time correction, the determination coefficient reached values from 0.75 to 0.89 for the depth of $0.05 \mathrm{~m}, 0.61$ to 0.82 for the depth of $0.10 \mathrm{~m}$ and 0.33 to 0.70 for the depth of $0.20 \mathrm{~m}$. Sándor and Fodor (2012) who carried out their studies under climatical conditions similar to those in Czech Republic reported that the peak soil temperature (calcaric arenosol) in the depth of 0.05 m occurred 6 hours later than the peak of the air temperature. Their results differ from ours mainly due to the distinctly different canopy character (wide row spaced maize vs. narrow row spaced wheat). 
Table 1. Regression analysis of dependence of hourly soil temperatures on hourly air temperatures in winter wheat canopy

\begin{tabular}{|c|c|c|c|c|}
\hline Year & Stage & $-0.05 \mathrm{~m}$ & $-0.10 \mathrm{~m}$ & $-0.20 \mathrm{~m}$ \\
\hline \multirow{3}{*}{2010} & I & $\begin{array}{c}\mathrm{y}=0.5348 \mathrm{x}+5.5539 \\
R^{2}=0.8329\end{array}$ & $\begin{array}{c}\mathrm{Y}=0.3772 \mathrm{x}+6.9439 \\
R^{2}=0.6691\end{array}$ & $\begin{array}{c}\mathrm{y}=0.2348 \mathrm{x}+8.1385 \\
R^{2}=0.4112\end{array}$ \\
\hline & II & $\begin{array}{c}\mathrm{y}=0.5971 \mathrm{x}+5.2177 \\
R^{2}=0.8427\end{array}$ & $\begin{array}{c}\mathrm{y}=0.452 \mathrm{x}+6.923 \\
R^{2}=0.7199\end{array}$ & $\begin{array}{c}\mathrm{y}=0.2967 \mathrm{x}+8.7678 \\
R^{2}=0.5199\end{array}$ \\
\hline & III & $\begin{array}{c}\mathrm{y}=0.5649 \mathrm{x}+7.0587 \\
R^{2}=0.8794\end{array}$ & $\begin{array}{c}\mathrm{y}=0.4104 \mathrm{x}+9.3943 \\
R^{2}=0.7422\end{array}$ & $\begin{array}{c}\mathrm{y}=0.2516 \mathrm{x}+11.704 \\
R^{2}=0.4866\end{array}$ \\
\hline \multirow{3}{*}{2011} & I & $\begin{array}{c}\mathrm{y}=0.3526 \mathrm{x}+6.8404 \\
R^{2}=0.7619\end{array}$ & $\begin{array}{c}\mathrm{y}=0.2512 \mathrm{x}+7.6228 \\
R^{2}=0.6145\end{array}$ & $\begin{array}{c}\mathrm{y}=0.1319 \mathrm{x}+8.6932 \\
R^{2}=0.3344\end{array}$ \\
\hline & II & $\begin{array}{c}\mathrm{y}=0.4522 \mathrm{x}+6.872 \\
R^{2}=0.8131\end{array}$ & $\begin{array}{c}\mathrm{y}=0.3426 \mathrm{x}+7.9506 \\
R^{2}=0.6605\end{array}$ & $\begin{array}{c}\mathrm{y}=0.2144 \mathrm{x}+9.2579 \\
R^{2}=0.3998\end{array}$ \\
\hline & III & $\begin{array}{c}\mathrm{y}=0.3678 \mathrm{x}+9.7235 \\
R^{2}=0.8091\end{array}$ & $\begin{array}{c}\mathrm{y}=0.2538 \mathrm{x}+11.21 \\
R^{2}=0.6837\end{array}$ & $\begin{array}{c}\mathrm{y}=0.1208 \mathrm{x}+12.924 \\
R^{2}=0.4004\end{array}$ \\
\hline \multirow{3}{*}{2013} & I & $\begin{array}{c}\mathrm{y}=0.6946 \mathrm{x}+2.7475 \\
R^{2}=0.8855\end{array}$ & $\begin{array}{c}\mathrm{y}=0.6155 \mathrm{x}+3.1928 \\
R^{2}=0.8199\end{array}$ & $\begin{array}{c}\mathrm{y}=0.5409 \mathrm{x}+3.9885 \\
R^{2}=0.7007\end{array}$ \\
\hline & II & $\begin{array}{c}\mathrm{y}=0.4282 \mathrm{x}+7.5356 \\
R^{2}=0.7527\end{array}$ & $\begin{array}{c}\mathrm{y}=0.3753 \mathrm{x}+8.1763 \\
R^{2}=0.6862\end{array}$ & $\begin{array}{c}\mathrm{y}=0.3349 \mathrm{x}+8.8461 \\
R^{2}=0.6219\end{array}$ \\
\hline & III & $\begin{array}{c}\mathrm{y}=0.4639 \mathrm{x}+9.537 \\
R^{2}=0.8067\end{array}$ & $\begin{array}{c}\mathrm{y}=0.3496 \mathrm{x}+11.306 \\
R^{2}=0.6816\end{array}$ & $\begin{array}{c}\mathrm{y}=0.2388 \mathrm{x}+13.332 \\
R^{2}=0.4043\end{array}$ \\
\hline
\end{tabular}

The coefficient of determination (Table 1) reaches values from 0.33 to 0.89 in dependence on the growth stage of plants and the depth of measurement. This coefficient differs slightly in the $0.2 \mathrm{~m}$ depth. From this point of view, it is possible to predict soil temperatures under winter wheat canopy from data of air temperature recorded in the near surface area in dependence on the winter wheat developmental stage. A similar analysis - prediction of daily soil temperature under the wheat canopy by air temperature was carried out by Ahmad and Rasul (2008). The coefficient of determination $\left(\mathrm{R}^{2}\right)$ ranged between 0.319 in the depth of $20 \mathrm{~cm}$ in the winter period (main vegetation period of wheat) and 0.865 in the depth of $0.10 \mathrm{~m}$ in spring. Toy et al. (1978) showed that air temperature may be viewed as a surrogate for soil temperature - a linear relationship between monthly soil and air temperatures has been found. Zheng et al. (1993) achieved good results in respect to modeling soil temperatures under the forest canopy by employing air temperatures and the leaf area index data according to the 
Beer-Lambert Law.

Modeling of hourly soil temperature under the winter wheat canopy for the depth of $0.05 \mathrm{~m}$ in April until July 2011 (Obo locality) was also performed. Correlation among variables was defined by linear regression of the hourly near surface air temperature (i.e. in $0.05 \mathrm{~m}$ height above soil surface) in the canopy and the delayed hourly soil temperature under canopy (outcome of cross correlation). The difference among the measured and modeled soil temperatures was -5.06 to $2.72^{\circ} \mathrm{C}$. When using multiple regression with quadratic spacing (modeling of hourly soil temperature in under canopy based on the hourly near surface air temperature and hourly soil moisture in the $0.10-0.40 \mathrm{~m}$ profile), the difference between the measured and modeled soil temperatures in the depth of $0.05 \mathrm{~m}$ was -2.16 to $2.37^{\circ} \mathrm{C}$. The regression equation $-21.5049+2.2846 \times x+2.5909 \times y-0.0127 \times$ $x^{2}-0.0822 \times x \times y-0.0618 \times y^{2}$ (when $\mathrm{x}=$ hourly near surface air temperature in $0.05 \mathrm{~m}$ height in ${ }^{\circ} \mathrm{C}$ and $\mathrm{y}=$ hourly soil moisture in $0.10-0.40 \mathrm{~m}$ profile in volume \%) enables relatively accurate modeling of soil temperatures $\left(\mathrm{R}^{2}=0.93\right)$ when compared with using alternative agrometeorological instruments.

\section{Conclusion}

The impact of year, locality (soil), winter wheat canopy structure and the growth stage on the soil temperature in various depths was determined. Detailed course of daily soil temperatures and their stratification in the soil profile for individual vegetation periods was expressed by $2 \mathrm{D}$ nomograms. The time delay of the air temperature course in the canopy and soil temperatures under canopy was quantified by cross correlation. The regression between soil temperature, air temperature and partly soil moisture in the winter wheat stand was established. These findings can be used in making more accurate prediction models of pathogens and pest occurrence on winter wheat, in models of crop and yield development, soil evaporation, soil heat fluxes etc.

Acknowledgments. This work was supported by project of the Ministry of Agriculture of the Czech Republic, project No. QJ1230056 and project CZ.1.07/2.3.00/20.0005. 


\section{References}

Ahmad M. F., Rasul G., 2008: Prediction of soil temperature by air temperature; a case study for Faisalabad. Pakistan Journal of Meteorology, 5, 9, 19-27.

Casanova J. J., Judge J., Jones J. W., 2006: Calibration of the CERES-maize model for linkage with a microwave remote sensing model. Transactions of the ASABE, 49, 3, 783-792.

Derron J. O., Bertossa M., Bruneti R., Colombi L., 2005: Flight phenology of western corn rootworm (Diabrotica virgifera virgifera) in Switzerland South of the Alps. Revue Suisse d'Agriculture, 37, 61-64.

Devine W. D., Harrington C. A., 2007: Influence of harvest residues and vegetation on microsite soil and air temperatures in a young conifer plantation. Agricultural and Forest Meteorology, 145, 125-138.

Fortin M. C., 1993: Soil temperature, soil water, and no-till corn development following in-row residue removal. Agronomy Journal, $\mathbf{8 5}, 3,571-\overline{576}$.

Franzaring J., Högy P., Erbs M., Fangmeier A., 2010: Responses of canopy and soil climate in a six year free-air $\mathrm{CO}_{2}$ enrichment study with spring crops. Agricultural and Forest Meteorology, 150, 354-360.

Gupta S. C., Radke J. K., Larson W. E., 1981: Predicting temperatures of bare and residue covered soils with and without a corn crop. Soil Science Society of America Journal, 45, 2, 405-412.

Han H., Ning T., Li Z., 2013: Effects of tillage and weed management on the vertical distrubution of microclimate and grain yield in a winter wheat field. Plant, Soil and Environment, 59, 5, 201-207.

He J., Li H., McHugh A. D., Wang Q., Li H., Rasaily R. G., Sarker K. K., 2012: Seed zone properties and crop performance as affected by three no-till seeders for permanent raised beds in arid Northwest China. Journal of Integrative Agriculture, 11, 10, $1654-1664$.

Hurtalová T., Matejka F., 1999: Surface characteristics and energy fluxes above different plant canopies. Agricultural and Forest Meteorology, 98-99, 491-500.

Chelle M., Liu S., Ney B., 2009: Which air temperature drives epidemiological processes of fungal folia wheat diseases at leaf scale? Association Française de Protection des Plantes, 9ème conférence international sur les maladies des plantes, Tours, France, 8 et 9 Décembre 2009, 464-471.

Ju Z., Hu Ch., Zhang Y., Chen S., 2010: Effects of temperature rising on soil hydrothermal properties, winter wheat growth and yield. In WS3.1 - Climate change: Agriculture, food security and human health. 9th European IFSA Symposium, Vienna, Austria. 1307-1316.

Krčmářová J., Pokorný R., Brotan J., Středová H., 2013: The course of soil temperature under wheat stand. In MendelNet 2013, Faculty of Agronomy: Mendel University in Brno, Czech Republic, 2013, 94-98.

Kurpelová M., Coufal L., Čulík J., 1975: Agroklimatické podmienky ČSSR. Hydrometeorologický ústav, Bratislava, 270 p. (in Slovak) 
Licht M. A., Al-Kaisi M., 2005: Strip-tillage effect on seedbed soil temperature and other soil physical properties. Soil and Tillage Research, 80, 233-249.

Luo Y., Loomis R. S., Hsiao T. C., 1992: Simulation of soil temperature in crops. Agricultural and Forest Meteorology, 61, 23-38.

Matejka F., Huzulák J., 1987: Canopy microclimate analysis (in Slovak). Bratislava: Veda. 228 p.

McMaster G. S., Wilhelm W. W., 1998: Is soil temperature better than air temperature for predicting winter wheat phenology? Agronomy Journal, 90, 602-607.

Meier U., 1997: BBC $\bar{H}$-Monograph. Growth stages of plants - Entwicklungsstadien von Pflanzen - Estadios de las plantas - Développement des Plantes. Blackwell Wissenschaftsverlag, Berlin und Wien, 622 p.

Němeček J., Macků J., Vokoun J., Vavříček D., Novák P., 2001: Taxonomický klasifikační systém půd České republiky. EZU a VÚMOP, Praha, 78 p. (in Czech)

Pierson F. B., Wight J. R., 1991: Variability of near-surface soil temperature on sagebrush rangeland. Journal of Range Management, 44, 5, 491-497.

Pokladníková H., Rožnovský J., 2006: The soil temperature at Pohořelice station during the years 1961 to 2000. Contrib. Geophys. Geod., 36, 3, 317-327.

Pokladníková H., Rožnovský J., 2007: Method of completing missing data of soil temperature. Contrib. Geophys. Geod., 37, 3, 247-261.

Porté A., Huard F., Dreyfus P., 2004: Microclimate beneath pine plantation, semi-mature pine plantation and mixed broadleaved-pine forest. Agricultural and Forest Meteorology, 126, 1-2, 175-182.

Prévost M., Pothier D., 2003: Partial cuts in a trembling aspen - conifer stand: effects on microenvironmental conditions and regeneration dynamics. Canadian Journal of Forest Research, 33, 1-15.

Rodskjer N., Tuvesson M., Wallsten K., 1989: Soil temperature during the growth period in winter wheat, spring barley and ley compared with that under a bare soil surface at Ultuna, Sweden. Swedish Journal of Agricultural Research, 19, 193-202.

Sándor R., Fodor N., 2012: Simulation of soil temperature dynamics with models using different concepts. The Scientific World Journal, 2012, article ID 590287, 8 p.

Sharma P., Shukla M. K., Sammis T. W., 2010: Predicting soil temperature using air temperature and soil, crop, and meteorological parameters for three specialty crops in southern New Mexico. Applied Engineering in Agriculture, 26, 1, 47-58.

Středa T., Vahala O., Středová H., 2013: Prediction of adult western corn rootworm (Diabrotica virgifera virgifera LeConte) emergence. Plant Protection Science, 49, 2, 89-97.

Středová H., Fukalová P., Středa T., 2012: Comparison of soil frost depth and its duration determined by soil frost tube and soil temperature interpolation. Contrib. Geophys. Geod., 42, 3, 255-268.

Toy T. J., Kuhaida A. J., Munson B. E., 1978: The prediction of mean monthly soil temperature from mean monthly air temperature, Soil Science, 126, 96-104.

Wang H., Cutforth H., McCaig T., McLeod G., Brandt K., Lemke R., Goddard T., Sprout C., 2009: Predicting the time to $50 \%$ seedling emergence in wheat using a Beta model. NJAS - Wageningen Journal of Life Sciences, 57, 65-71. 
Weber P., Rennenberg H., 1996: Exchange of $\mathrm{NO}$ and $\mathrm{NO}_{2}$ between wheat canopy monoliths and the atmosphere. Plant and Soil, 180, 197-208.

Wort D. J., 1940: Soil temperature and growth of Marquis Wh $\underline{\text { Weat. }}$. Plant Physiology, 15, $2,335-342$.

Zheng D., Hunt E. R., Running S. W., 1993: A daily soil temperature model based on air temperature and precipitation for continental applications. Climate Research, 2, 183-191.

Žalud Z., Brotan J., Hlavinka P., Trnka M., 2013: Trends in temperature and precipitation in the period of 1961-2010 in Žabčice locality. Acta Universitatis Agriculturae et Silviculturae Mendelianae Brunensis, 61, 5, 1521-1531. 